\title{
CHEMICAL COMPOSITION OF SKELETAL MUSCLE
}

\author{
ABRÃo ANGHIHAN * \\ Francisco B. DE Jorge ** JULINHo AISEN ***
}

The striated muscular tissue constitutes about $50 \%$ of the corporal weight. The material to be used for its study may be easily obtained and, if necessary, repeated samples may be collected without damage to the organism.

A review of the pertinent literature on this subject shows that, while there is a large number of references concerning the hydroelectrolytic content of striated muscle in lower chordates, very little information is obtainable concerning man.

The purpose of the present work is to determine the contents of water, sodium, potassium, calcium, magnesium, phosphorus, copper and iron of the tibialis anterior, deltoid and pectoralis major muscles in man. It is hoped that the results obtained may constitute a basis for later comparative studies on the chemical composition of muscles during pathological conditions.

\section{MATERIAL AND METHODS}

During necropsy, 53 fragments of muscles were excised from 41 corpses, less than 24 hours after death. Os these samples, 29 were of anterior tibial muscle (26 males and 3 females: 19 white, 9 mulattoes and 1 negro, ages varying from 4 to 63 years); the remaining 12 samples comprised deltoid and pectoral major muscles (10 males and 2 females: 7 white and 5 mulattoes, ages ranging from 9 to 60 years).

The causes of death included: craniocerebral trauma of several types (21 cases), polytrauma (9), drowning (4), post-traumatic internal hemorrhage (4), heart attack (1), asphyxia (1) and lesions in the neck produced by shot-gun (1).

The muscle samples were dried in an oven at $105^{\circ} \mathrm{C}$ until constant weight. These dry tissues were incinerated in a furnace regulated potentiometrically at $550^{\circ} \mathrm{C}$ during approximately 12 hours (overnight). Ash solutions were prepared using $2 \mathrm{~N}$ hydrochloric acid.

From the Departments of Neurology (* Assistant professor, *** Assistant neurosurgeon) and Medicine (** Chief of Laboratory), University of São Paulo School of Medicine, São Paulo, Brazil.

Acknowledgements - The authors acknowledge Dr. Arnaldo Siqueira, Director of Medicolegal Institute of São Paulo, the permission for remotion of muscles fragments at the post mortem examination of cases included in this study. 
Sodium and potassium were determined by flame spectrophotometry, calcium by the method of Clark and Collip ${ }^{1}$ (1925), phosphorus by the method of Fiske and Subbarow ${ }^{5}$ (1925), iron by the method of Wong ${ }^{7}$ (1928), magnesium by Titan yellow (De Jorge et al., 1964) ${ }^{3}$ and copper by diethyldithiocarbamate (De Jorge et al., 1962$)^{2}$.

\section{R E S L T S}

Data obtained by the above mentioned methods were analyzed by conventional statistical tests and the results obtained are presented in Table 1.

\section{COM M E N T S}

Table 2 summarizes the statistical significance of the difference of the means in the chemical constituents of anterior tibial, pectoral major and deltoid muscles.

The water content of the three muscles is very similar, ranging from 75.18 to $75.91 \mathrm{~g} / 100 \mathrm{~g}$. In spite of the fact that the sodium concentrations ranged only from 3.30 mequiv/100 $\mathrm{g}$ in the deltoid muscle to 4.36 mequiv/ $100 \mathrm{~g}$ in the pectoral major muscle, the differences of the means are significant. The anterior tibial muscle presents higher potassioum and iron contents and contents of copper, calcium and phosphorus lower than in the two other muscles.

Previous data do not allow us to make any interpretation of the above results; the differences observed may be due just to the fact that the muscles considered belong to different body regions with different activities and it is advanced that they may be related to results obtained with muscles under different pathological conditions.

Comparing the above mentioned results with those presented by Table 3 in "Documenta Geigy-Scientific Tables" ${ }^{4}$ (1956), which presents data obtained by several investigators, it is to be noticed that: a) our results are fairly similar on what concerns sodium ( 3.74 to $3.14 \mathrm{mg}$ ), magnesium ( 1.86 to $1.92 \mathrm{mEq}$ ) and copper (124.1 to $125 \mathrm{mg}$ ); b) cur values are higher in regard to potassium (11.22 to $9.23 \mathrm{mEq})$ and calcium $(8.90$ to $7.0 \mathrm{mg}$ ); c) they are lower in regard to phosphorus $(220$ to $159 \mathrm{mg})$; the Table 3 mentioned before does not present data on iron.

On the other hand, analyzing the results included on the table mentioned by Lorenzi ${ }^{6}$, which includes data obtained by different authors and recalculating these values according to the same units used by us, it is seen that, excluding the series of Eliel et al. and those of Wilson and Lorenzi, the others do not allow a significant comparison, due to the small number of cases examined. In the series of Eliel et al. and Wilson and Lorenzi, the values presented are very similar to those obtained by us; those authors, however, did not determine the contents of $\mathrm{Ca}, \mathrm{Mg}, \mathrm{Cu}$ and Fe. 


\begin{tabular}{|c|c|c|c|c|c|c|c|c|}
\hline Muscles & $\begin{array}{l}\text { Water } \\
\mathrm{g} / 100 \mathrm{~g}\end{array}$ & $\begin{array}{c}\text { Sodium } \\
\mathrm{mEq} / 100 \mathrm{~g}\end{array}$ & $\begin{array}{l}\text { Potassium } \\
\mathrm{mEq} / 100 \mathrm{~g}\end{array}$ & $\begin{array}{l}\text { Calcium } \\
\mathrm{mg} / 100 \mathrm{~g}\end{array}$ & $\begin{array}{l}\text { Magnesium } \\
\mathrm{mEq} / 100 \mathrm{~g}\end{array}$ & $\begin{array}{l}\text { Phosphorus } \\
\mathrm{mg} / 100 \mathrm{~g}\end{array}$ & $\begin{array}{l}\text { Copper } \\
\mu \mathrm{g} / 100 \mathrm{~g}\end{array}$ & $\begin{array}{c}\text { Iror } \\
\mathrm{mg} / 100 \mathrm{~g}\end{array}$ \\
\hline $\begin{array}{l}\text { Tibialis } \\
\text { anterior }\end{array}$ & $\begin{array}{c}75.49 \pm \\
0.95 \\
\mathrm{n}=29\end{array}$ & $\begin{array}{c}3.74 \pm \\
0.41 \\
\mathrm{n}=29\end{array}$ & $\begin{array}{c}11.22 \pm \\
1.83 \\
\mathbf{n}=29\end{array}$ & $\begin{array}{c}8.89 \pm \\
1.22 \\
\mathrm{n}=29\end{array}$ & $\begin{array}{c}1.86 \pm \\
0.15 \\
\mathbf{n}=29\end{array}$ & $\begin{array}{c}159.0 \pm \\
11.2 \\
\mathrm{n}=29\end{array}$ & $\begin{array}{r}124.2 \pm \\
8.5 \\
\mathrm{n}=29\end{array}$ & $\begin{array}{c}5.54 \pm \\
0.35 \\
\mathbf{n}=29\end{array}$ \\
\hline $\begin{array}{l}\text { Pectoralis } \\
\text { major }\end{array}$ & $\begin{array}{c}75.18 \pm \\
1.87 \\
\mathbf{n}=12\end{array}$ & $\begin{array}{c}4.36 \pm \\
0.42 \\
\mathrm{n}=12\end{array}$ & $\begin{array}{c}3.49 \pm \\
0.45 \\
\mathbf{n}=9\end{array}$ & $\begin{array}{c}10.49 \pm \\
0.86 \\
\mathrm{n}=12\end{array}$ & $\begin{array}{c}1.69 \pm \\
0.25 \\
\mathbf{n}=12\end{array}$ & $\begin{array}{r}193.5 \pm \\
13.5 \\
\mathrm{n}=12\end{array}$ & $\begin{array}{c}230.0 \pm \\
37.3 \\
\mathbf{n}=12\end{array}$ & $\begin{array}{c}2.16 \pm \\
0.40 \\
\mathrm{n}=12\end{array}$ \\
\hline Deltoid & $\begin{array}{c}75.91 \\
1.57 \\
\mathrm{n}=12\end{array}$ & $\begin{array}{c}3.30 \pm \\
0.72 \\
\mathrm{n}=12\end{array}$ & $\begin{array}{c}2.66 \pm \\
0.40 \\
\mathbf{n}=9\end{array}$ & $\begin{array}{c}10.00 \pm \\
1.09 \\
\mathrm{n}=12\end{array}$ & $\begin{array}{c}1.59 \\
0.24 \\
\mathbf{n}=12\end{array}$ & $\begin{array}{c}190.3 \pm \\
11.9 \\
\mathrm{n}=12\end{array}$ & $\begin{array}{c}343.9 \pm \\
81.4 \\
\mathbf{n}=12\end{array}$ & $\begin{array}{c}2.49 \pm \\
0.50 \\
\mathrm{n}=12\end{array}$ \\
\hline
\end{tabular}

Table 1 - Results (fresh weight).

\begin{tabular}{lcccc}
\hline & $\begin{array}{c}\text { Water } \\
\mathrm{g} / 100 \mathrm{~g}\end{array}$ & $\begin{array}{c}\text { Sodium } \\
\mathrm{mEq} / 100 \mathrm{~g}\end{array}$ & $\begin{array}{c}\text { Potassium } \\
\mathrm{mEq} / 100 \mathrm{~g}\end{array}$ & $\begin{array}{c}\text { Calcium } \\
\mathrm{mg} / 100 \mathrm{~g}\end{array}$ \\
\hline
\end{tabular}

M. tibialis anterior $\times M$. pectoralis major

\begin{tabular}{|c|c|c|c|c|c|c|c|c|}
\hline$t$ & 0.704 & 4.368 & 12.327 & 4.112 & 2.697 & 8.418 & 14.600 & 26.837 \\
\hline$P$ & $>0.40$ & $<0.001$ & $<0.001$ & $<0.001$ & $>0.001$ & $<0.001$ & $<0.001$ & $<0.001$ \\
\hline freedom $n_{1}+n_{2}-2$ & $2=39$ & 39 & 36 & 39 & 39 & 39 & 39 & 39 \\
\hline
\end{tabular}

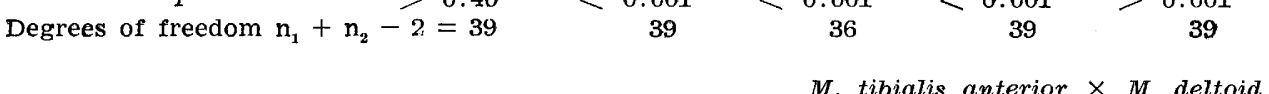

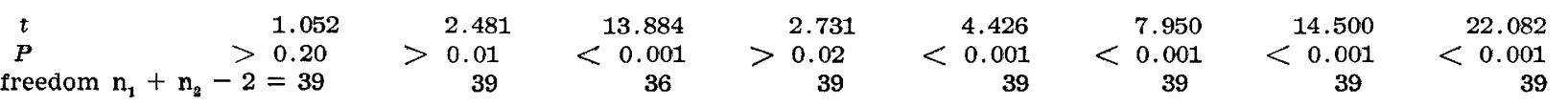

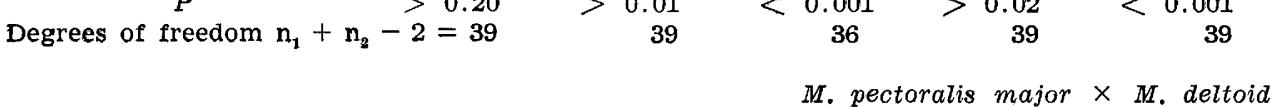

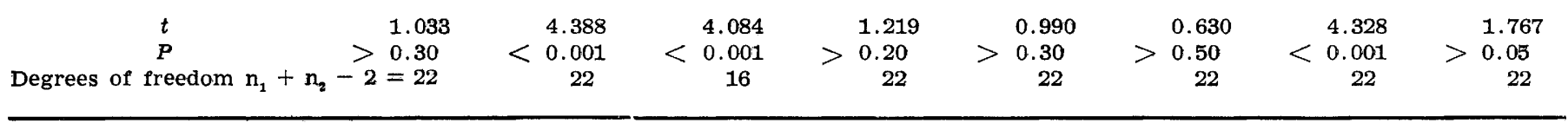

Table 2 - Significance of the differences between the means of the concentrations in $M$. tibialis anterior, deltiod and perctoralis major. 
It should be noticed that the material studied by Lorenzi was obtained during surgery and not from cadavers. The comparison of the data obtained by him and by us shows that the results obtained in cadavers before 24 hours after death are fairly similar to those obtained from living specimens. Also, it may be - and further research should prove it - that in regard to the other elements investigated by us similar concentrations should be found in both conditions, as suggested by the data provided in the Geygi Documenta.

\section{S U M M A R Y}

The present paper aims to presents standard values for the contents of water, sodium, potassium, calcium, magnesium, phosphorus, copper and iron in muscles (tibialis anterior, deltoid and pectoralis major) in individuals without any neurological conditions. This study shall constitute the basis for the interpretation of other data, still being gathered, relating these normal values with those obtained for muscles under pathological conditions.

\section{R E S M O}

Os autores determinaram o conteúdo em água, sódio, potássio, cálcio, magnésio, fósforo, cobre e ferro em músculos estriados (tibial anterior, deltóide e grande peitoral) de indivíduos sem afecção neurológica. Este estudo constitui base para estudos comparativos na composição química de afecções neuromusculares.

\section{R E F E R E N E S}

1. CLARK, E. P. \& COLLIP, J. B. - A study of the Tisdall method for determination of blood calcium with a suggested modification. J. biol. Chem. 63:461, 1925.

2. De JORGE, F. B.; CANElAS, H. M. \& COSTA-SIlva, A. - Contribuição ao estudo do metabolismo do cobre: metodologia da determinação do cobre em materiais biológicos. Rev. paul. Med. 61:350, 1962.

3. De JORGE, F. B.; SIlva, A. G. \& UlHôA CINTRA, A. B. - Determinação quantitativa de magnésio nos materiais biológicos. Rev. paul. Med. 64:224, 1964.

4. DoCUmenta Geigy - Scientific Tables. Geigy, Basle, 5a. ed. 1956 (pág. 282).

5. FISKE, C. H. \& SUBBAROW, Y. - The colorimetric determination of phosphorus. J. biol. Chem. 66:375, 1925.

6. LORENZI, L. - Contenuto in acqua, potassium, sódio, cloro e fosforo del musculo scheletico umano normale. Sperimentale 109:619, 1959.

7. WONG, S. Y. - Colorimetric determination of iron and hemoglobin in blood. J. biol. Chem. 77:409, 1928. 